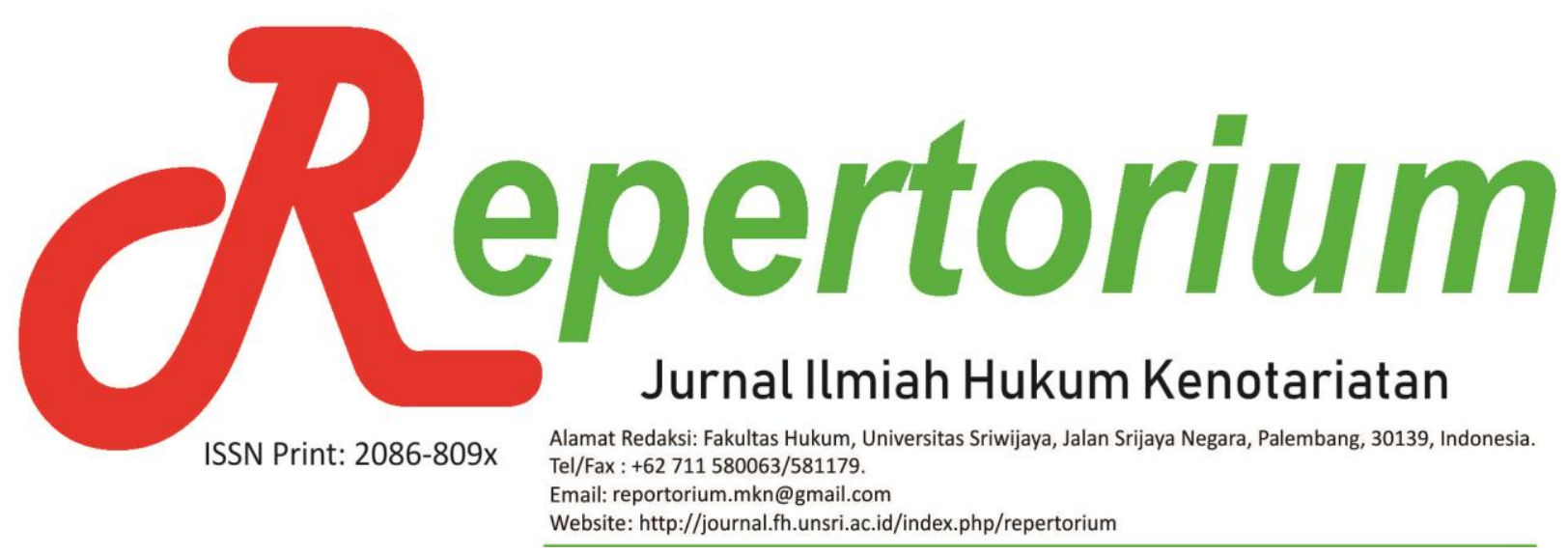

\title{
LIMITASI KEWENANGAN \\ MAJELIS PENGAWAS NOTARIS DAERAH KOTA PALEMBANG \\ DALAM PENANGANAN PELANGGARAN KODE ETIK YANG DILAKUKAN NOTARIS
}

\author{
Deva Apriza*
}

\begin{abstract}
Abstrak: Penelitian ini bertujuan untuk mengetahui latar belakang dan penerapan Limitasi Kewenangan Majelis Pengawas Notaris Daerah Kota Palembang dalam Penanganan Pelanggaran Kode Etik yang Dilakukan Notaris. Jenis penelitian ini yaitu penelitian hukum normatif dengan menggunakan studi pustaka dan wawancara guna mendapatkan data dalam penelitian ini. Metode yang digunakan pendekatan secara pustaka digunakan untuk menganalisis berbagai peraturan perundangundangan terkait dengan Majelis Pengawsas Daerah dalam menjalankan kewenangannya. Hasil penelitian ini menyatakan bahwa Kewenangan Majelis Pengawas berdasarkan Undang-undang Jabatan Notaris hanya meliputi pelanggaran terhadap UUJN itu sendiri, ketika terjadi pelanggaran terhadap kode etik notaris, maka berdasarkan Pasal 12 Anggaran Dasar Ikatan Notaris Indonesia, merupakan kewenangan Dewan Kehormatan Notaris, meskipun dalam menjalankan kewenangannya Dewan Kehormatan dapat berkoordiinasi dengan Majelis Pengawas namun pelaksanaan sidang etiknya tetap menjadi kewenangan Dewan Kehormatan. Apabila pelanggarannya terhadap kode etik PPAT maka berdasarkan Pasal 33 PP Nomor 24 Tahun 2016 menjadi kewenangan Majelis Kehormatan PPAT.
\end{abstract}

Kata kunci: Majelis Pengawas; Majelis Kehormatan; Notaris; Kode Etik.

* Magister Kenotariatan Fakultas Hukum Universitas Sriwijaya

\section{LATAR BELAKANG}

Kehadiran jabatan Notaris dikehendaki oleh aturan hukum dengan tujuan untuk membantu dan melayani masyarakat yang membutuhkan alat bukti tertulis yang bersifat autentik mengenai peristiwa, keadaan, atau suatu perbuatan hukum.

Notaris adalah pejabat publik dengan satu-satunya wewenang untuk membuat akta kesepakatan kontrak atau keputusan dengan yang diharuskan oleh hukum untuk diformulasikan dalam dokumen yang dikonfirmasi. notaris juga ber- 
tanggung jawab untuk mengatur tanggal akta, untuk menyimpan untuk memberikan grosse yang sah atau salinan atau kutipan sebagian dari perbuatan, asalkan pembuatan akta tidak ditugaskan kepada pejabat publik lainnya dan hanya tugas eksklusif dari notaris.

Kode Etik Notaris Ikatan Notaris Indonesia (I.N.I) merupakan sekumpulan kaedah moral yang wajib ditaati oleh seluruh anggota perkumpulan dan semua orang yang menjalankan tugas jabatan sebagai Notaris, termasuk di dalamnya para Pejabat Sementara Notaris, Notaris Pengganti dan Notaris Pengganti Khusus. Hal tersebut berdasarkan Pasal 1 huruf b Kode Etik Notaris Ikatan Notaris Indonesia (I.N.I).

Pelanggaran terhadap Kode Etik yang sampai masuk dalam ranah peradilan juga terjadi di Kota Palembang dengan nomor perkara Nomor: 27/Pdt.G/2013/PN.PLG. Perkara tersebut mengenai seorang Notaris Kota Palembang yang telah membuat Akta Jual Beli Nomor 1693/SU.II/2010 dalam kasus tersebut telah terjadi pemalsuan dokumen berupa identitas dan tandatangan salah satu pihak, yaitu pihak penjual.

Berdasarkan latar belakang tersebut diatas, permasalahan yang akan dibahas dalam penelitian ini secara terperinci dapat dirumuskan sebagai berikut:

1. Apakah limitasi Kewenangan Majelis Pengawas Notaris Daerah Kota Palembang dalam penanganan pelanggaran kode etik yang dilakukan oleh Notaris membebaskan sama sekali Majelis Pengawas Notaris Daerah dalam penanganan pelanggaran kode etik, analisis Putusan PN Kota Palembang Nomor 27/Pdt.G/2013/PN.PLG ?
2. Faktor-faktor apa yang menghambat dan mendukung pelaksanaan Kewenangan Majelis Pengawas Notaris Daerah Kota Palembang Dalam Penanganan Pengaduan yang terdapat Pelanggaran Kode Etik Yang Dilakukan Oleh Notaris ?

\section{Kerangka Teori}

\section{Grand Theory}

Teori Kewenangan

Menurut H.D Stout wewenang adalah pengertian yang berasal dari hukum organisasi pemerintahan, yang dapat dijelaskan sebagai seluruh aturan-aturan yang berkenaan dengan perolehan dan penggunaan wewenang-wewenang pemerintahan oleh subjek hukum publik didalam hubungan hukum publik.

Diharapkan dengan adanya substansi teori kewenangan, setiap keputusan Majelis Pengawas Notaris Daerah Kota Palembang dalam penanganan Pelanggaran Kode Etik yang dilakukan oleh Notaris dapat terlaksana dalam upaya mewujudkan dan memenuhi rasa keadilan masyarakat melalui putusan-putusan yang diambilnya dalam penyelesaian perkara.

\section{Middle Range Theory}

\section{Teori Pengawasan}

Dalam middle range theory terdapat teori pengawasan, hal ini terdapat kaitannya dengan pengawasan yang ditujukan kepada notaris. Pengawasan adalah proses pengamatan daripada pelaksanaan seluruh kegiatan organisasi untuk menjamin agar semua pekerjaan yang sedang dilaksanakan berjalan sesuai dengan rencana yang telah ditentukan sebelumnya.

Rumusan di atas menjelaskan bahwa yang menjadi pokok dari pengawasan adalah agar segala hak dan kewajiban yang 
diberikan kepada Notaris oleh peraturan perundang-undangan senantiasa dilakukan sesuaidengan koridor yang telah ditentukan, bukan saja jalur hukum tetapi juga dasar moral dan etika profesi demi terjaminnya perlindungan hukum dan kepastian hukum bagi masyarakat.

\section{Applied Theory}

Teori Jabatan

Dalam applied theory terdapat teori mengenai jabatan, Logemann menyatakan, bahwa jabatan adalah lingkungan pekerjaan tetap yang digaris batasi dan yang disediakan untuk ditempati oleh pemangku jabatan yang ditunjuk dan disediakan untuk diwakili oleh mereka sebagai pribadi. Berdasarkan hukum tata negara, jabatanlah yang dibebani dengan kewajiban, yang berwenang untuk melakukan perbuatan hukum. Hak dan kewajiban berjalan terus, tidak terpengaruh dengan pergantian pejabat.

\section{Kerangka Konseptual}

\section{Majelis Pengawas}

Fungsi pengawasan terhadap Notaris merupakan kewenangan dari Menteri Hukum dan Hak Asasi Manusia sebagaimana tersebut di dalam Pasal 67 ayat 1 UUJNP, yang dalam pelaksanaannya membentuk Majelis Pengawas Notaris mulai dari tingkat pusat dilaksanakan oleh Majelis Pengawas Notaris Pusat, tingkat Provinsi oleh Majelis Pengawas Notaris Wilayah dan tingkat Kabupaten/Kota oleh MPD. Hal yang demikian terdapat pada Pasal 67 ayat 2, Pasal 68 dan Pasal 69 Undang-Undang Jabatan Notaris Perubahan.

Keanggotaan dari Majelis Pengawas Notaris tingkat pusat, wilayah dan daerah sebanyak sembilan orang dan dengan kom- posisi tiga elemen sebagaimana tersebut di pada Pasal 67 ayat (3) UUJNP bahwa:

1. Pemerintah sejumlah tiga.

2. Organisasi Notaris sejumlah tiga.

3. Akademisi sejumlah tiga.

Majelis Pengawas dari tingkat pusat hingga tingkat daerah memiliki kewenangan yang berbeda-beda, sebagaimana yang telah terdapat pada Pasal 69 hingga Pasal 81 UUJNP. Begitu terperincinya pengaturan mengenai pengawasan terhadap Notaris sebagaimana yang diamanatkan oleh Undang-Undang diharapkan pengawasan dan pembinaan dapat berjalan dengan efektif.

\section{Kode Etik Notaris}

Definisi kode etik berdasarkan Pasal 1 ayat ( 2 ) Kode Etik menyebutkan bahwa;

"Kode Etik adalah seluruh kaidah moral yang ditentukan oleh Perkumpulan Ikatan Notaris Indonesia berdasarkan Keputusan Kongres Perkumpulan dan/atau yang ditentukan dan diatur dalam Peraturan Perundang - Undangan yang mengatur tentang hal itu dan yang berlaku bagi, serta wajib ditaati oleh setiap dan semua anggota perkumpulan dan semua orang yang menjalankan tugas dan jabatan sebagai Notaris, Termasuk di dalam nya para Pejabat Sementara Notaris, Notaris Pengganti, dan Notaris Pengganti Khusus."

Berdasarkan pengertian mengenai kode etik di atas, maka kedudukan kode etik sangatlah penting bagi profesi jabatan Notaris, dikarenakan dalam kode etik terkadung kaedah-kaedah moral yang hal tersebut dapat dijadikan pedoman bagi perilaku diri Notaris baik pada saat melaksanakan 
jabatannya juga pada kesehariannya. Sehingga dengan adanya Kode Etik Notaris, Notaris dapat menjalankan jabatannya dengan profesional dan berintegritas.

\section{Metode}

\section{Tipe Penelitian}

Penelitian yang akan dilakukan merupakan penelitian hukum normatif. Penelitian hukum normatif menganalisis suatu keberlakuan hukum yang dilakukan dengan meneliti bahan-bahan hukum, seperti penelitian terhadap asas-asas hukum, hukum positif, aturan hukum, dan kaedah-kaedah hukum.

Pendekatan Penelitian

Penelitian yang akan dilakukan menggunakan tiga metode pendekatan dalam penelitian hukum untuk menjawab permasalahan, yaitu :

1) Pendekatan Konseptual (Conceptual Approach)

2) Digunakan untuk memahami konsep yang berkaitan dengan kewenangan, pengawasan, dan jabatan notaris selaku pejabat umum yang berwenang untuk membuat akta autentik.

3) Pendekatan Perundang-undangan (Statute Approach)

4) Ibrahim menyatakan "Penelitian Normatif tentu harus menggunakan perundang-undangan, karena yang akan diteliti adalah berbagai aturan hukum yang menjadi fokus sekaligus tema sentral dalam suatu penelitian".

5) Pendekatan Kasus (Case Approach)

6) Pendekatan kasus (case approach) dalam penelitian normatif mempunyai tujuan untuk mempelajari pen- erapan norma-norma atau kaidah hukum yang dilakukan dalam praktik jabatan Notaris. Pendekatan jenis ini biasanya digunakan mengenai kasus-kasus yang telah mendapat putusan.

\section{Bahan Penelitian}

Bahan penelitian meliputi sebagai berikut :

1. Bahan Hukum Primer.

2. Bahan hukum primer adalah bahan hukum yang mempunyai kekuatan mengikat, bersumber dan/atau yang dikeluarkan oleh lembaga resmi, meliputi peraturan perundangundangan yang berkaitan dengan pokok bahasan penelitian.

3. Bahan Hukum Sekunder.

4. Bahan hukum sekunder adalah bahan hukum yang memberikan penjelasan terhadap bahan hukum primer, seperti rancangan undangundang, hasil-hasil penelitian, jurnal ilmiah, hasil seminar atau pertemuan ilmiah lainnya, dokumen pribadi atau pendapat dari kalangan pakar hukum sepanjang relevan dengan pokok bahasan penelitian, serta bahan-bahan yang diperoleh dari internet.

5. Bahan Hukum Tersier

6. Bahan hukum tersier adalah bahan hukum penunjang yang memberi petunjuk dan menjelaskan bahan hukum primer dan bahan hukum sekunder. Seperti kamus, ensiklopedia, kamus hukum, surat kabar, majalah, sepanjang memuat informasi yang relevan.

Bahan hukum dikumpulkan melalui prosedur inventarisasi dan identifikasi secara normatif melalui peraturan perundang-undangan dan peraturan-peraturan 
terkait lainnya, melalui teknologi informasi (internet) serta melakukan wawancara dengan narasumber sesuai permasalahan penelitian.

\section{Analisis Data}

Analisis data adalah kegiatan menguraikan, membahas, menafsirkan data-data yang diperoleh dari penelitian. Data yang diperoleh dari hasil penelitian kepustakaan maupun penelitian lapangan dianalisis dengan menggunakan analisis yang secara kualitatif, artinya sebagai prosedur penelitian yang menghasilkan data deskriptif berupa kata-kata tertulis atau lisan dari orang-orang dan prilaku yang dapat diamati.

\section{ANALIS DAN DISKUSI}

Pelanggaran terhadap Kode Etik yang sampai masuk dalam kompetensi peradilan terjadi di Kota Palembang dengan nomor perkara Nomor: 27/Pdt.G/2013/PN.PLG. Perkara tersebut mengenai seorang Notaris Kota Palembang yang telah membuat Akta Jual Beli Nomor 1693/SU.II/2010 berdasarkan pemalsuan dokumen berupa identitas dan tandatangan salah satu pihak, yaitu pihak penjual. Akta Jual Beli tersebut dibuat pada tahun 2010, sedangkan bukti kepemilikan atas tanah berupa sertipikat yang menjadi dasar jual-beli masih atas nama pemilik tanah yang sudah meninggal pada tahun 2009, dengan demikian Akta Jual Beli tersebut jelas tidak dimungkinkan dihadiri apalagi di tandatangani oleh pihak penjual.

Tindakan Notaris tersebut atas Akta Jual Beli yang dibuatnya jelas telah melanggar kode etik Pasal 3 angka 4 Kode Etik Profesi Notaris mengenai bertindak jujur, mandiri, tidak berpihak, penuh rasa tanggung jawab, berdasarkan peraturan perundang-undangan dan isi sumpah jabatan
Notaris. Berdasarkan pelanggaran tersebut pihak yang merasa dirugikan atas kasus Akta Jual Beli Nomor 1693/SU.II/2010 melaporkan Notaris yang bersangkutan kepada Majelis Pengawas Daerah Notaris Kota Palembang. Majelis Pengawas Daerah Kota Palembang menggelar sidang kode etik yang putusannya diberikan oleh Majelis Pengawas Wilayah Sumatera Selatan dan dijadikan sebagai salah satu alat bukti dalam perkara perdata di Pengadilan Negeri Kota Palembang dengan Nomor Putusan 27/Pdt.G/2013/PN.PLG.

Perkara serupa juga terdapat pada Putusan Pengadilan Tinggi DKI Jakarta Nomor 545/PDT/2017/PT.DKI. Pada putusan tersebut dijelaskan mengenai perbuatan yang dilakukan oleh TERGUGAT-I dengan TERGUGAT-II yang telah merugikan PARA PENGGUGAT secara melawan hukum dengan mengalihkan obyek a quo yang nyata-nyata masih dalam penguasaan PARA PENGGUGAT kepada TERGUGAT-II, maka atas perbuatan TERGUGAT-III, PARA PENGGUGAT mengirimkan surat pengaduan kepada MAJELIS PENGAWAS DAERAH NOTARIS ADMINISTRASI JAKARTA TIMUR Tanggal 20 Mei 2014 terkait pelanggaran Undang-Undang Jabatan Notaris No. 2 Tahun 2014.

Jika dilihat dari kasus tersebut di atas, tindakan pemeriksaan yang dilakukan oleh Majelis Pengawas Daerah Kota Palembang terhadap pelanggaran yang dianggap melanggar Kode Etik Notaris, tidak tepat. Hal tersebut dikarenakan kewenangan pemeriksaan dalam ranah etik merupakan ranah internal perkumpulan, sehingga dalam hal ini berdasarkan yang telah penulis uraikan di atas, yaitu dalam melakukan pengawasan sekaligus pembinaan berdasar- 
kan Pasal 1 angka 8 KEN yang menyebutkan Dewan Kehormatan adalah alat perlengkapan Perkumpulan yang dibentuk dan berfungsi menegakkan Kode Eik, harkat dan martabat notaris, yang bersifat mandiri dan bebas dari keberpihakan, dalam menjalankan tugas dan kewenangannya dalam Perkumpulan.

Sedangkan Majelis Pengawas memiliki kewenangan yang berbeda. Jika melihat pada tempus delicti kasus tersebut terjadi pada tahun 2010, sehingga dasar yang penulis gunakan untuk menentukan kewenangan Majelis Pengawas, yaitu mengacu pada UUJN sebelum perubahan, yaitu Undang-Undang Nomor 30 Tahun 2004 tentang Jabatan Notaris. Berdasarkan UUJN sebelum perubahan, kewenangan majelis pengawas selain meliputi perilaku notaris dan pelaksanaan jabatannya juga memiliki kewenangan berdasarkan Pasal 66, yaitu untuk kepentingan proses peradilan, penyidik, penuntut umum, atau hakim dalam mengambil fotokopi Minuta Akta dan/atau surat-surat yang dilekatkan pada Minuta Akta atau Protokol Notaris dalam penyimpanan Notaris; dan memanggil Notaris untuk hadir dalam pemeriksaan yang berkaitan dengan Akta atau Protokol Notaris yang berada dalam penyimpanan Notaris, maka harus dengan persetujuan Majelis Pengawas Notaris.

Pada Undang-Undang Jabatan Notaris sebagaimana telah diubah dengan Undang-Undang Nomor 2 tahun 2014, kewenangan yang diampu oleh Majelis Pengawas telah digantikan oleh Majelis Kehormatan Notaris, hal tersebut termuat dalam Pasal 66 menggantikan bunyi Pasal 66 sebelumnya, yaitu:

Untuk kepentingan proses peradilan, penyidik, penuntut umum, atau ha- kim dengan persetujuan majelis kehormatan Notaris berwenang: mengambil fotokopi Minuta Akta dan/atau surat-surat yang dilekatkan pada Minuta Akta atau Protokol Notaris dalam penyimpanan Notaris; dan memanggil Notaris untuk hadir dalam pemeriksaan yang berkaitan dengan Akta atau Protokol Notaris yang berada dalam penyimpanan Notaris.

Dengan demikian jelas kewenangan Majelis Pengawas adalah meliputi perilaku notaris dan pelaksanaan jabatannya berdasarkan UUJN. Pada kasus di Pengadilan Negeri Kota Palembang dengan Nomor Putusan 27/Pdt.G/2013/PN.PLG disebutkan bahwa tindakan Notaris atas Akta Jual Beli yang dibuatnya jelas telah melanggar kode etik Pasal 3 angka 4 Kode Etik Profesi Notaris mengenai bertindak jujur, mandiri, tidak berpihak, penuh rasa tanggung jawab, berdasarkan peraturan perundang-undangan dan isi sumpah jabatan Notaris, sehingga berdasarkan pelanggaran tersebut pihak yang merasa dirugikan atas kasus Akta Jual Beli Nomor 1693/SU.II/2010 melaporkan Notaris yang bersangkutan kepada Majelis Pengawas Daerah Notaris Kota Palembang. Berdasarkan laporan pihak yang merasa dirugikan tersebut diatas, Majelis Pengawas Daerah Kota Palembang menggelar sidang kode etik yang putusannya diberikan oleh Majelis Pengawas Wilayah Sumatera Selatan dan dijadikan sebagai salah satu alat bukti dalam perkara perdata di Pengadilan Negeri Kota Palembang. Secara yuridis 
formal berdasarkan yang telah penulis uraikan, maka yang berwenang memeriksa pelanggaran atas Pasal 3 angka 4 Kode Etik Profesi Notaris adalah Dewan Kehormatan Notaris, bukanlah Majelis Pengawas.

Pada prakteknya masyarakat umum secara awam kurang mengetahui mengenai perbedaan mekanisme pelaporan terkait pelanggaran terhadap UUJN, Kode Etik Notaris, maupun Kode Etik PPAT sehingga seringkali apabila terjadi pelanggaran baik terhadap UUJN, Kode Etik Notaris, ataupun Kode Etik PPAT, masyarakat melakukan pelaporan secara umum kepada Majelis Pengawas Daerah. Meskipun bukan kewenangan Majelis Pengawas Daerah dalam menangani pelanggaran kode etik namun terhadap adanya laporan dari masyarakat, Majelis Pengawas Daerah dapat menerima laporan tersebut dan melakukan pemeriksaan terhadap laporan pelanggaran yang diterimanya. Hal tersebut seakan menjadi wewenang Majelis Pengawas Daerah dan tidak membebaskan sama sekali dalam menangani semua pelanggaran, meskipun pada akhirnya terhadap persoalan pengaduan yang diterima oleh Majelis Pengawas Daerah dilimpahkan dan/atau diteruskan kepada Majelis atau Organisasi yang berwenang sebagaimana Putusan PN Palembang

Nomor 27/PDT.G/2013/PN.PLG.

Dengan demikian maka pejabat pembuat akta dalam hal ini Notaris "M" tidak dapat diperiksa atau di sidang etik oleh Majelis Pengawas Notaris. Pelanggaran terhadap PP 24 Tahun 2016 dapat diberikan tindakan oleh Majelis Kehormatan yang dibentuk oleh Mentri yang dalam hal ini adalah mentri dalam bidang agraria/pertanahan, hal tersebut sesuai dengan yang termuat dalam Pasal 33 PP Nomor 24 Tahun 2016, yaitu:

1) Menteri melaksanakan pembinaan dan pengawasan terhadap pelaksanaan tugas PPAT.

2) Tata cara pembinaan dan pengawasan sebagaimana dimaksud pada ayat (1) diatur lebih lanjut dengan Peraturan Menteri.

Namun kaitannya dengan pelanggaran terhadap Kode Etik, maka yang berwenang melakukan pengawasan dan penindakan berdasarkan Pasal 7 Kode Etik PPAT, yaitu:

Pengawasan atas pelaksanaan Kode Etik ini dilakukan dengan cara sebagai berikut:

1) Pada tingkat pertama oleh Pengurus Daerah IPPAT dan Majelis Kehormatan Daerah bersama-sama dengan Pengurus Wilayah dan seluruh anggota perkumpulan IPPAT;

2) pada tingkat terakhir oleh Pengurus Pusat IPPAT dan Majelis Kehormatan Pusat.

Sehingga apabila ditinjau dari kasus dalam Putusan 27/Pdt.G/2013/PN.PLG, maka pelanggaran atas Kode Etik yang terjadi seharusnya adalah pelanggaran terhadap Kode Etik PPAT.

Faktor penghambat pelaksanaan kewenangan Majelis Pengawas Daerah Kota Palembang dalam penanganan pengaduan yang terdapat pelanggaran kode etik yang dilakukan oleh Notaris

Secara yuridis hambatan Majelis Pengawas Daerah untuk penanganan pengaduan yang terdapat pelanggaran kode etik adalah secara substansial majelis pengawas daerah tidak menimbulkan wewenang terhadap pe- 
nanganan pelanggaran kode etik oleh Notaris.

Sedangkan dalam hambatan yang sering ditemui oleh Majelis Pengawas Daerah pada masing-masing daerah dalam pengawasan secara berkala yakni 1 (satu) tahun sekali berdasarkan perintah UUJN, yaitu :

Waktu

Majelis Pengawas Daerah yang terdiri dari tiga unsur yang berbeda memiliki implikasi yang berbeda juga. Ketiga unsur tersebut memiliki profesi yang berbeda-beda sehingga kesulitan untuk menentukan waktu yang sama bagi ketiga unsur tersebut. Hal ini dikarenakan ketiga unsur tersebut harus hadir secara bersamaan dalam melaksanakan pemeriksaan yang dilakukan secara berkala.

Mengingat salah satu kewenangannya adalah melakukan pemeriksaan secara berkala, maka kendala waktu juga mempengaruhi pada proses tindak lanjut pengaduan masayarakat terhadap notaris yang ditangani oleh Majelis Pengawas Daerah, hal ini dikarenakan Majelis Pengawas Daerah harus membentuk tim pemeriksa. Pembentukan tim pemeriksa terkendala oleh waktu, karena sulitnya menyatukan waktu yang dimiliki oleh ketiga unsur Majelis Pengawas Daerah.

Wilayah dan jumlah notaris yang diawasi Jumlah Majelis Pengawas Notaris Daerah pada prinsipnya tidak sebanding dengan pertumbuhan jumlah notaris yang semakin banyak di wilayah yang tergolong cukup luas. Saat ini menurut Ibu Neliwati, S.H., M.H selaku Pengawas Notaris Daerah Kota Palembang dari bagian Instansi Pemerintahan Kanwil Kementerian Hukum dan Hak
Asasi Manusia Republik Indonesia, untuk data jumlah Notaris di Kota Palembang pada tahun 2017 adalah sebanyak 216 (dua ratus enam belas) orang, sementara untuk jumlah Notaris di Provinsi Sumatera Selatan tercatat diatas 300 (tiga ratus) orang lebih Notaris. Dari jumlah Notaris di Kota Palembang sebanyak 216 (dua ratus enam belas) orang tersebut, untuk masing-masing tim, memeriksa sebanyak 72 (tujuh puluh dua) Notaris di Kota Palembang.

Fasilitas yang dimiliki Majelis Pengawas Notaris Daerah

Menurut Neliwati selaku majelis Pengawas dari unsur Instansi Pemerintah yakni Kanwil Kementerian Hukum dan Hak Asasi Manusia Kota Palembang, di Kota Palembang sendiri untuk ketersediaan anggaran, sarana dan prasarana masih sangat minim dalam artian belum ada dukungan penuh dari pemerintah untuk penyediaan anggaran khusus berikut sarana dan prasarana yang mendukung pelaksanaan tugas Majelis Pengawas Notaris Daerah Kota Palembang dalam melakukan pengawasan dan pemeriksaan terhadap Notaris.

\section{Adanya Rasa Tidak Enak Memeriksa Rekan Sejawat \\ Menurut Neliwati, SH.,MH., Faktor peng- hambat dalam melakukan pembinaan secara rutin terhadap Notaris yaitu munculnya rasa tidak enak karena adanya salah satu unsur}


dari Majelis Pengawas Notaris Daerah yang juga dari unsur notaris, akan tetapi pada prakteknya unsur notaris inilah yang memberi masukan kepada 2 unsur lainnya (pemerintah dan akademisi) karena notaris lah yang paling menguasai praktek di lapangan. Demikian pula yang diungkapkan oleh Neliwati, SH., MH. , walaupun hambatan dalam hal rasa tidak enak tersebut tidak terlalu signifikan.

Tidak Adanya Laporan Notaris Pindah Alamat Kantor

Disamping faktor-faktor yang telah disebutkan diatas, faktor penghambat lain yang menjadi kendala Majelis Pengawas Notaris Daerah dalam melakukan pengawasan terhadap Notaris, menurut Dr. $\mathrm{Hj}$. Nashriana, SH., M.Hum. , yakni Notaris yang pindah alamat terkadang tim pengawas tidak mendapatkan informasi dan/atau tidak jarang Notaris yang bersangkutan tidak melakukan pelaporan untuk pindah alamat kantor.

Sistem Administrasi Pada Kantor Notaris yang Tidak Memenuhi Standar

Kendala lain yang paling banyak ditemui dilapangan antara lain adalah :

1. Sistem administrasi kantor yang belum terpenuhi.

2. Minuta akta yang tidak dibundel.

3. Notaris tidak memenuhi dokumendokumen/buku yang menjadi protokol Notaris

Berikut akan dikemukakan faktor pendukung dalam pelaksanaan kewenangan majelis pengawas notaris daerah kota $\mathrm{Pa}-$ lembang dalam penanganan pelanggaran kode etik yang dilakukan oleh Notaris yakni sebagai berikut :
1. Dilakukan pembinaan secara rutin terhadap Notaris, oleh karena itu Majelis Pengawas Notaris Daerah terus mengadakan pengawasan dan pembinaan secara rutin kepada notaris setidaknya 1 tahun sekali;

2. Berdasarkan hasil wawancara dengan Notaris/PPAT Rispa Medya Sari, SH., M.Kn beliau memaparkan faktor pendukung untuk mendukung kinerja Majelis Pengawas Notaris Daerah dalam mencegah perbuatan melawan hukum yang dilakukan oleh Notaris di Kota Palembang, yaitu Majelis Pengawas Notaris Daerah diangkat secara resmi oleh Kementerian Hukum dan Ham Republik Indonesia. Sehingga menjadikan Majelis Pengawas Notaris Daerah semakin mantap dan maksimal dalam bertugas serta dapat mewujudkan Notaris di Kota Palembang yang tertib hukum dan tidak terjebak dalam perbuatan yang melanggar UUJN maupun Kode Etik.

3. Faktor pendukung lainnya juga adalah berupa adanya kegiatan seminar mengenai perlindungan hukum terhadap Notaris, yang mana pembicaranya terdapat dari berbagai kalangan yakni dari Praktisi, Akademisi, Kementerian Hukum dan Ham, dari Kepolisian Negara Republik Indonesia, dari organisasi Ikatan Notaris Indonesia (INI), dari Pengurus Wilayah, Ketua Umum Ikatan Pejabat Pembuat Akta Tanah (IPPAT) dan lain sebagainya, hal tersebut selain menjadi ajang silaturahmi antara para Notaris yang tergabung dalam Organisasi Ikatan Notaris Indonesia, dapat diikuti juga oleh kalangan Mahasiswa/i yang sedang menempuh pendidikan Magister Kenotariatan, dan para 
Calon Notaris yang sedang menempuh magang.

Sedangkan faktor pendorong

Majelis Pengawas Notaris Daerah dalam melakukan pembinaan secara rutin terhadap Notaris yaitu :

1. Diharapkan akan semakin banyak Notaris yang taat hukum dengan adanya pembinaan rutin;

2. Dengan jumlah Notaris yang selalu meningkat dan dengan dilaksanakannya pengawasan secara rutin, maka akan dapat terlaksananya ketertiban dan pelaksanaan jabatan Notaris yang sesuai dengan aturan Undang-Undang Jabatan Notaris dan Kode Etik Notaris.

Faktor pendukung lainya yakni adanya semangat dari kesamaan profesi agar profesi Notaris dapat menjadi profesi yang terhormat dan berwibawa. Hal tersebut bertujuan untuk memberikan pelayanan dan kepastian hukum bagi masayarakat sehingga tercipta budaya tertib hukum. Dan faktor pendukung yang tak kalah penting merupakan bentuk pengawasan yang dilakukan Majelis Pengawas Notaris Daerah dengan keterbatasan yang ada termasuk fasilitas, Majelis Pengawas Notaris Daerah mampu melaksanakan tugas dan kewajibannya. Hal tersebut terbukti dengan semakin berkurangnya jumlah pelanggaran yang dilakukan oleh notaris tiap tahunya karena pengawasan dan pembinaan rutin yang dilakukan oleh Majelis Pengawas Notaris Daerah.

\section{KESIMPULAN DAN SARAN}

Berdasarkan dari hasil penelitian dan pembahasan, dapat disimpulkan sebagai berikut:

1. Secara yuridis yang berwenang memeriksa pelanggaran Kode Etik Profesi Notaris adalah Dewan Kehormatan No- taris, bukanlah Majelis Pengawas. Meskipun dalam hal ini bukan kewenangan dari Majelis Pengawas Daerah menangani pelanggaran kode etik, namun Majelis Pengawas Daerah harus lebih dahulu melakukan pemeriksaan terhadap laporan pelanggaran yang diterimanya, hal tersebut seakan menjadi wewenang Majelis Pengawas Daerah dan tidak membebaskan sama sekali dalam menangani semua pelanggaran, meskipun pada akhirnya laporan terhadap pelanggaran tersebut ada yang dilimpahkan dan/atau diteruskan kepada Majelis atau Organisasi Notaris yang berwenang sebagaimana putusan Pengadilan Negeri Palembang terhadap Perkara Nomor: 27/Pdt.G/2013/PN.PLG.

2. Secara yuridis hambatan Majelis Pengawas Daerah untuk penanganan pengaduan yang terdapat pelanggaran kode etik adalah secara substansial majelis pengawas daerah tidak menimbulkan wewenang penanganan pelanggaran kode etik oleh Notaris. Faktor pendukung dalam pelaksanaan kewenangan Majelis Pengawas Notaris daerah kota Palembang dalam penanganan pengaduan atas pelanggaran yang dilakukan oleh Notaris yakni : 
3. Majelis Pengawas Daerah diangkat secara resmi oleh Kementerian Hukum dan Ham Republik Indonesia berdasarkan perintah dari UUJN mempunyai wewenang mengawasi dan berkewajiban untuk memeriksa terlebih dahulu atas pengaduan tentang pelanggaran yang dilakukan oleh Notaris, meskipun terdapat pelanggaran kode etik;

Berdasarkan hasil penelitian dan pembahasan yang telah dikemukakan, maka disarankan sebagai berikut :

1. Harus dipertegas rumusan wewenang Majelis Pengawas Daerah, bahwa Majelis Pengawas Daerah berwenang memeriksa atas semua pengaduan yang diterima dari masyarakat dan kemudian meneruskannya kepada Majelis atau Organisasi Notaris yang lebih tinggi apabila terdapat pelanggaran kode etik.

2. Perlu sosialisasi lebih jelas lagi kepada masyarakat maupun penegak hukum sehingga dapat membedakan kewenangan dan pengawasannya terhadap Notaris dan PPAT, dikarenakan kedua jabatan tersebut memiliki kewenangan dan lembaga pengawasan yang berbeda.

3. Guna mendukung jalannya fungsi pengawasan, diharapakan pemerintah segera menyelesaikan segala hambatan dalam pengawasan yang dilakukan oleh Majelis Pengawas Notaris Daerah, seperti pemenuhan fasilitas berupa kantor dan transportasi dan hal lain yang dapat menunjang pelaksanaan fungsi pengawasan ini secara maksimal

\section{DAFTAR PUSTAKA}

\section{Buku}

Adjie, Habib, 2008, Sanksi Perdata dan Administratif Terhadap Notaris, PT. Refika Aditama, Bandung. , 2009, Hukum Notaris Indonesia, Refika Aditama, Bandung.

HR, Ridwan, 2013, Hukum Administrasi Negara, PT Raja Grafindo Persada. Jakarta.

Ibrahim, Johni, 2007, Teori \& Metodologi Penelitian Hukum Normatif, cet. III, Bayumedia Publishing, Malang.

Moelong, Lexy J., 2001, Metodologi Penelitian Kualitatif, PT. Remaja Rosdakarya, Bandung.

\section{Makalah dan Jurnal}

Yuanitasari, Deviana, Juli 2017, The Role Of Public Notary in Provinding Legal Protection on Standart Contract For Indonesian Consumers, Sriwijaya Law Riview, Fakultas Hukum Universitas Sriwijaya, Volume 1 Issue 2, hlm 180

Erna, Ristiani, 2010, "Peran dan Fungsi Majelis Pengawas Daerah Terhadap Pelaksanaan Tugas dan Jabatan Notaris ", Jurnal Mimbar Hukum, Yogyakarta.

Sidharta, Bernard Arief. 2001. Disiplin Hukum Tentang Hubungan Antara Ilmu Hukum, Teori Hukum, dan Filsafat Hukum (State Of The Arts). Makalah disampaikan dalam Rapat Tahunan Komisi Disiplin Ilmu Hukum. Jakarta 11-13 Februari

\section{Peraturan Perundang-undangan}

Kitab Undang-Undang Hukum Perdata Undang-Undang Republik Indonesia Nomor 30 Tahun 2004 tentang 
Jabatan Notaris, Lembaran Negara

Tahun 2004 Nomor 34.

Undang-Undang Republik Indonesia Nomor 2 Tahun 2014 tentang Perubahan Undang-undang Nomor 30 Tahun 2004 tentang Jabatan Notaris, Lembaran Negara Tahun 2012 Nomor 3.

Keputusan Menteri Hukum dan Hak Asasi Manusia Republik Indonesia Nomor M.39-PW.07.10 Tahun 2004 tentang Pedoman Pelaksanaan Tugas Majelis Pengawas Notaris.

Peraturan Menteri Hukum dan Hak Asasi Manusia Republik Indonesia Nomor M.02.PR.08.10 Tahun 2004 tentang Tata Cara Pengangkatan Anggota, Pemberhentian Anggota, Susunan Organisasi, Tata Kerja, Dan Tata Cara Pemeriksaan Majelis Pengawas Notaris.

\section{Kode Etik Notaris}

Putusan Mahkamah Konstitusi Republik Indonesia Nomor 49/PUU- X/2012 Putusan Pengadilan Negeri Palembang, "Putusan Nomor 27/Pdt.G/2013/PN.PLG.

Putusan Pengadilan Tinggi DKI Jakarta, "Putusan Nomor Nomor 545/PDT/2017/PT.DKI. 